One may expect to see an increasing use of the public policy argument in restrictive covenant cases in those states which have recently enacted legislation against other forms of racial discrimination. While the technique employed by the Ontario court does not appear to be readily adaptable to the American legal system, the decision does constitute an invitation to those state courts which are unsympathetic to restrictive covenants to limit the influence of the Corrigan decision.

\title{
LEGALITY OF WAGE READJUSTMENT PLANS UNDER THE OVERTIME PROVISION OF THE FAIR LABOR STANDARDS ACT
}

The most troublesome question which the Fair Labor Standards Act of $193^{x}$ has presented to the courts has been the interpretation of that part of Section 7 (a) of the Act which provides that the employee shall be paid for overtime work at not less thian one and one-half times "the regular rate at which he is employed." In attempting to comply with this.provision of the Act the employer is confronted with several problems. In the first place he wishes to maintain his wages and hours at their former over-all level, so that his.labor costs will not be increased by compliance. In the second place he wishes to avoid the necessity for spreading work brought about by extra labor cost for extra hours, since it may be uneconomical for him to reallocate the work in his plant for an increased force of workers, all of whom work only regular time; likewise labor unions whose members would suffer from reduced take-home pay by such a result might find it to their interest to support plans designed to avoid it. ${ }^{3}$ And in the

took the position that the court should consider evidence of the notorious dearth of housing for Negroes in the District of Columbia in making its decision whether to enforce a restrictive covenant. The same judge took a similar position in his dissent in Mays v. Burgess, ${ }_{52}$ F. 2d I23, I26, I27 (App. D.C., I946).

${ }^{1} 52$ Stat. 1060 (1938), 29 U.S.C.A. \$\$ 20I-219 (1942).

$\Rightarrow$ The full text of Section 7 (a) is as follows: No employer shall, except as otherwise provided in this section, employ any of his employees who is engaged in commerce or in the production of goods for commerce-

(I) for a workweek longer than forty-four hours during the first year from the effective date of this section,

(2) for a workweek longer than forty-two hours during the second year from such date, or

(3) for a workweek longer than forty hours after the expiration of the second year from such date,

unless such employee receives compensation for his employment in excess of the hours above specified at a rate not less than one and one-half times the regular rate at which he is employed.

3 The Act was designed primarily for the relief of unorganized, unskilled, and unemployed workers. Presidential messages, I94I Wage \& Hour Man. 747 (I937), and 82 Cong. Rec. Ir (1937). Its passage met with opposition from some labor unions, particularly the American Federation of Labor, which in 1937 went on record opposing it. N.Y. Times, p. I, col. 2 (May 24, r937), because it feared that the minimum wage would tend to become the maximum wage. It was estimated by the Department of Labor that by 1945 upwards of $x, 000,000$ workers would receive wage increases because of the law, but $4,000,000$ would have their hours 
third place both employer and employeemay find it desirable to stabilize weekly wages, a result which the Act's emphasis on the hourly wage may tend to hinder. The numerous plans produced by yarious employers in attempts to solve one or another of these problems and still comply with the Act have forced the courts to search for a definition of "regular rate" and to reconsider the aims of the Act.

Ordinarily the legality of the scheme will depend on whether the new hourly rate used in computing overtime payments is considered the "regular rate" as required by the Act, or merely an arbitrary or fictitious figure. Thus, where before the Act an employer paid a fixed weekly wage of $\$ 4$ o for variable hours and, to meet the requirements of the Act, commutes the salary into a $\$ \mathrm{I}$ an hour wage but provides that, should an employee work more than 40 hours a week, the statutory maximum, his hourly rate would be reduced in such a way that the regular plus overtime rate would still average $\$$ I per hour, it is obvious that Section 7 (a) has not been satisfied because the reduced rate which would be used in computing the overtime wage was not the "regular rate," but an entirely fictitious figure. The arrangement is in effect a contract to pay straight time regardless of the number of hours worked. ${ }^{4}$ While the scheme in the foregoing case is quite transparent, courts have been presented with plans which, though aiming at the same result, have been far more ingenious and plausible, and which have therefore presented a difficult problem of interpretation.

On June 8, 1942, the Supreme Court of the United States handed down two decisions on this question, Overnight Motor Transportation Co. v. Missel, 5 and Walling v. A. B. Belo Corp. ${ }^{6}$ Their joining on the Supreme Court calendar suggests that the Court intended to give a comprehensive clarification of a somewhat muddled situation. The continued, if not increased, amount of litigation since these two cases indicates how unsuccessful this attempt has been.

This unfortunate result has followed from the ever more apparent inconsistency of the two cases which was quite evident to the four dissenting justices in the Belo case. In the Missel case the employer paid a fixed salary for fluctuating hours in excess of the statutory maximum. There was no fixed hourly rate, but the salary was large enough to cover both regular and overtime work at the statutory minimum hourly rate. ${ }^{7}$ This plan, the court held, was unsatisfactory

of work reduced. In practice, therefore, this provision of the Act was expected to be a worksharing rather than a wage-raising measure. N.Y. Times, $\$$ I, p. r2, col. 3 (Aug. I4, I938). The actual consequences of the Act in this connection are dificult to analyze, since the supervening defense and war programs created an abnormal condition in the labor market.

4 Cf. Walling v. Green Head Bit \& Supply Co., I38 F. 2d 453 (C.C.A. Ioth, I943).

${ }^{5} 316$ U.S. 572 (1942).

${ }^{6} 316$ U.S. 624 (I942).

7 The employee worked, on the average, 65 hours and received $\$ 27.50$. At this time the legal minimum for the first 42 hours was $\$ .30$. His regular pay at the minimum would therefore have been $\$ 12.60$; his overtime pay for 23 hours at $\$ .45$, \$10.35. His total compensation at the minimum rate, $\$ 22.95$, would therefore have been less than what he actually received. 
because the "regular rate" was not, as was assumed in the plan, the statutory minimum rate, but rather the average hourly rate, or the quotient of the total wage divided by the hours worked, and overtime payment was one and onehalf times the regular rate for hours employed beyond the statutory maximum. ${ }^{8}$ This construction of Section 7 (a), the Court felt, was necessary to give effect to the aim of the Act which, it said, was not only to raise substandard wages, but also, by requiring extra pay for overtime regardless of how high the regular rate is, to induce the employer to spread employment. ${ }^{9}$

In the Belo case the employer, to meet the requirements of the Act, had converted a fixed weekly salary for variable hours into an hourly wage. To keep the weekly pay stabilized at the then current figure, he entered into contracts with his employees individually which in each case specified a basic hourly rate for the legal maximum regular hours and not less than one and one-half times that rate per hour for overtime, with a guaranty of a weekly minimum pay approximating the old salary. Under this plan the employee worked about ten hours more than the statutory maximum regular hours before he became entitled to any pay in addition to his weekly guaranty, and when he did he received surplus compensation at one and one-half times the basic hourly contract rate. ${ }^{10}$ The basic rate was in all cases in excess of the legal minimum. The Court, in a five-tofour decision, upheld this formula because the basic contract rate was the "regular rate" within the meaning of Section 7 (a) and there was nothing in the Act which prohibited the payment of more for overtime than one and one-half times the basic rate, as was often the effect of the guaranteed weekly minimum. The Missel case was distinguished on the ground that in that case there was no stated hourly wage and no provision for overtime. .I $^{\text {In }}$

Although it is easy to point to some distinguishing facts between the two cases, the basic theories and even the broad dicta in the two cases are difficult to reconcile. In the Missel case the Court defines "regular rate" as the quotient of the weekly wage divided by the number of hours worked, ${ }^{12}$ which rate is then used in computing the overtime pay, while in the Belo case a contract rate which does not correspond to the quotient is acceptable. Thus the plan in the Missel case could easily be legalized under the Belo decision by setting up a more or

${ }^{8}$ Thus if the workweek is 65 hours the average hourly rate in this case is $\$ .423(\$ 27.50 \div 65)$. Since the worker is entitled to an additional 50 per cent of the regular rate for the 23 hours of overtime, he must be paid an additional $\$ 4.86\left(\$ .2 I_{15} \times 23\right)$. His total pay will therefore be $\$ 32.36$.

${ }^{9}$ This conclusion is borne out by the legislative history of the Act. H.R. Rep. No. ${ }^{442}$, 75th Cong., Ist Sess. (1937). In the debates in Congress over the Act this object of spreading employment was emphasized by Senators Barkley and Healy. 8I Cong. Rec. 794I, 7848 (1938). See the Federal Wages and Hours Act, 52 Harv. L. Rev. 646, 665, 677 (r939).

so A typical contract provided that the regular rate would be $\$ .67$ for the first 44 hours, the then statutory maximum for regular hours, and one and one-half times this, or $\$ \mathrm{r}$, for overtime hours. The weekly guaranty was $\$ 40$. To earn more than the guaranty the employee in this pazticular example had to work more than $54 \frac{1}{2}$ hours, and when he did he received si per hour.

$$
{ }^{12} 3^{16} \text { U.S. } 624,634 \text { (I942). } \quad{ }^{12} 316 \text { U.S. } 572,580 \text { n. I6 (I942). }
$$


less arbitrary hourly rate without changing any condition of employment. Therefore, as Mr. Justice Reed points out in his dissent, if the congressional intent behind Section 7(a) was, as was reasonably assumed in the Missel case, to spread employment, it was frustrated in the Belo case. ${ }^{13}$

Ever since the district court's decision of the Belo case it has been the mainstay of employers in frequent litigations with employees or with the Wage and Hour Administrator. The Supreme Court decision in the case came at a very opportune time for many employers. Shortly before, in Carleton Screw Products Co. v. Fleming, ${ }^{\text {t4 }}$ the Circuit Court of Appeals for the Eighth Circuit had indicated that bonuses were subject to overtime payments under Section 7 (a). The Administrator had from the very first urged that the Act applied to piecework earnings, as was later held by the Supreme Court in United States v. Rosenwasser. ${ }^{15}$ With the Missel case eliminating the fixed above-minimum wage plan, a new and legal, but not uneconomical, readjustment plan was needed. Under the Belo holding a workweek longer than the legal maximum can be retained without an increase in pay. This is done by fixing by agreement a "regular rate" at or above the legal minimum, yet low enough to produce, if multiplied by the hours worked, a figure smaller than the old weekly wage. The old wage can then be paid in the form of a minimum or by adding bonuses. Since 1942 a large portion of the litigation concerning the Fair Labor Standards Act has involved plans aiming at a similar result and their scrutiny by the courts to determine whether the contract rate set was "regular" or fictitious.

Although in the Belo case the Court apparently based its decision on the presence of an agreed-upon regular rate, it was not prevented from holding two years later in Walling v. Helmerich $\&^{\circ}$ Payne, Inc. ${ }^{16}$ that the agreed-upon rates in the so-called "split-day" plan were fictitious. Under the split-day plan a long workday of ten hours, for example, is divided into two shifts. The first five hours are assigned a specified hourly rate above the legal minimum, which is the "regular rate"; the remaining five hours are treated as overtime and their rate is one and one-half times the "regular rate." The regular and overtime rates are so calculated as to insure that the total wages for each workday would continue the same as before the Act. ${ }^{77}$ At first glance the plan appears generous, in that

${ }^{13} 316$ U.S. 624,635 (1942). The inconsistency of the two cases is even more apparent from the lower court's opinion in the Belo case, in which it was stated that the purpose of the overtime provisions of the Act was not to discourage or limit overtime, but to raise substandard wages. Fleming v. A. H. Belo Corp., $\mathrm{x}_{21}$ F. 2d 207, 215 (C.C.A. 5th, 194r). This interpretation of Section 7 (a) is clearly contrary to that in the Missel case. See Overtime Compensation Under the Fair Labor Standards Act for Workers with a Fluctuating Number of Hours per Week, 52 Yale L. J. I59 (I942).

I 126 F. 2d 537 (C.C.A. 8th, 1942).

${ }^{15} 323$ U.S. 360 (x944).

${ }^{16} 323$ U.S. 37 (1944).

17 If a worker's daily wage was $\$ 5$ before the Act, his regular rate would be set at $\$ .40$ per hour. Under the split-day plan he would receive $\$ 2$ for the regular shift of the first five hours and time and one-half or $\$ 3$ for the second or overtime shift of the remaining five hours. His daily wage of $\$ 5$ would thus be retained. 
time and a half is paid forless than 40 hours, but it is evident that an extra workday bringing the total weekly time over 40 hours would produce no change in the average effective rate..$^{18}$ The Court, basing its holding on the aim of the overtime provision as interpreted by the Missel case, reversed the lower courts and held the plan illegal, because to approve such an artificial scheme, it felt, "would exalt ingenuity over reality." "Is The Belo case, on which both lower courts had relied for their decision, was distinguished in a somewhat summary fashion. ${ }^{20}$

The trend of the decisions, especially as evidenced by the cases before the lower federal courts, has been away from the Belo case. Cases where no hourly rate was set though the weekly wages were above the minimum have presented little difficulty and have been disposed of under the Missel case. ${ }^{2 x}$ Where the plan has included an agreed-upon rate, the first and obvious limitation has been that this contract rate must be one actually known and accepted by the employees; a mere bookkeeping transaction is insufficient. ${ }^{22}$ Where the contract rate is subject to change with the number of hours worked, it is not the regular rate within the Act. ${ }^{23}$ In cases very similar to the Belo case courts have frequently found distinguishing facts, though sometimes with doubtful perception. Thus, in Walling v. Richmond Screw Anchor Co., ${ }^{24}$ the court, faced with a plan that differed from the Belo plan only in that the employees received a bonus instead of a minimum guaranty in addition to set hourly wages, held it void under the Helmerich decision. The Belo case, the circuit court said, "offers difficulty" because it "involved a pay arrangement both unique and difficult to analyze." ${ }_{25}$ Of the very few cases that have purported to follow Walling v. Belo Corp., most have not involved the real problem of that case, but rather an actual reduction

${ }^{18}$ Under the described split-day plan of to hours the employee would have to work 8 days a week or, at least, 80 hours a week before his average effective rate would be increased. A similar split-day plan was held unlawful in Walling v. Alaska Pacific Consol. Min. Co., I52 F. 2d 8 r $_{2}$ (C.C.A. gth, I945).

${ }^{29} 3^{23}$ U.S. 37, 42 (I944).

${ }^{20}$ Ibid.

${ }^{2 x}$ Warren-Bradshaw Drilling Co. v. Hall, $3{ }^{7} 7$ U.S. 88 (I942); United States v. Rosenwasser, 323 U.S. 360 (r944); Seneca Coal \& Coke Co. v. Lofton, $x 36$ F. 2 d 359 '(C.C.A. Ioth, I943), cert. den. 320 U.S. 772 (x943); Kreeft v. R. W. Bates Piece Dye Works, Inc., I50 F. 2d 8I8 (C.C.A. 2d, I945); Landreth v. Ford, Bacon \& Davis, I47 F. 2 d 446 (C.C.A. 8th, I945); Kappler v. Republic Pictures Corp., 59 F. Supp. II2 (Iowa, 1945); Lorber v. Rosow, 58 F. Supp. 34I (Conn., I944); Walling v. Stone, I3I F. 2d 46x (C.C.A. 7th, 1942); Tidewater Optical Co. v. Wittkamp, I79 Va. 545, I9 S.E. 2d 897 (r942); Fleming v. Pearson Hardwood Flooring Co., 39 F. Supp. 300 (Tenn., I94I); St. John v. Brown, 38 F. Supp. 385 (Tex., I94I).

${ }^{2}$ Walling v. Castle, I53 F. 2 d 923 (C.C.A. 5th, r946); Walling v. West Kentucky Coal Co., 6o F. Supp. 68I (Tenn., I944); Seneca Coal \& Coke Co. v. Lofton, $x_{36}$ F. 2 d 359 (C.C.A. Ioth, I943), cert. den. 320 U.S. 772 (r943).

${ }^{23}$ Walling v. Green Head Bit \& Supply Co., I38 F. 2d 453 (C.C.A. Ioth, I943).

${ }^{24} 59$ F. Supp. $29 \mathrm{r}$ (N.Y., I945).

${ }^{25} 59$ F. Supp. 29I, 293 (N.Y., I945); see also Carleton Screw Products Co. v. Fleming, I26 F. 2 d 537 (C.C.A. 8th, I942), decided before the Belo case was affirmed by the Supreme Court. 
of the effective hourly rate by agreement with employees. ${ }^{26}$ This is permissible despite the fact that Section I 8 of the Act purports to forbid such a result, since that section has been held to be no more than a pious hope. ${ }^{27}$

The latest indication of the questionable effect of the Belo case as a precedent came with two recent and again simultaneous decisions of the Supreme Court. In Walling v. Youngerman-Reynolds Hardwood Co. ${ }^{28}$ the employees had formerly received piecework wages. After the Act the employer and workers agreed upon a regular hourly rate above the legal minimum, but less than the hourly average earned by piecework; for overtime hours $15^{\circ}$ per cent of the regular rate was to be paid. However, if the piecework earnings at the old rate exceeded the wages at the hourly rate, as they almost-invariably did, the workers would be entitled to the piecework wages. The second case, Walling v. Harnischfeger Corp. ${ }^{29}$ involved essentially the same plan, with the difference that the agreedupon "regular rate" was more closely related to hourly piecework earnings, or, as it was there called, incentive bonus pay. In fact, the overtime hourly rate exceeded, though not by $5^{\circ}$ per cent, the piecework earnings per hour. ${ }^{3 \circ}$ The Supreme Court held both of these plans unlawful because in both cases the regular rate set up by agreement was not the significant figure of the contract and overtime should have been computed by adding $5 \circ$ per cent to the average hourly piecework earnings. The Court defined "regular rate" as the quotient of the weekly earnings divided by the number of hours worked ${ }^{3 x}$-the definition

${ }^{26}$ In White v. Witwer Grocer Co., ${ }^{32}$ F. 2 d 108 (C.C.A. 8th, I942) the hourly rate was reduced after the Act from $\$ .35$ to $\$ .3 \mathrm{I}$ and the new rate was the basis of all payments. No minimum or bonuses were involved. Likewise in Shepler v. Crucible Fuel Co. of America, $60 \mathrm{~F}$. Supp. 260 ( $\mathrm{Pa}$., I943), a fixed monthly wage was commuted into a hourly wage which became the effective rate. The cases that have actually followed the Belo case have presented fact situations almost identical with that case. Walling v. Halliburton Oil Well Cementing Co., I52 F. $2 d 622$ (C.C.A. 9th, I945); Atlantic Co. v. Walling, I3I F. $2 d$ 1 18 (C.C.A. 5th, I942).

27 In a few early cases actual reductions were held unlawful. Williams v. General Mills, 39 F. Supp. 849 (Ohio, I94I); Anuchick v. Transamerican Freight Lines Inc., 46 F. Supp. $86 \mathrm{r}$ (Mich., 1942). Since then, however, it has become clear that Section I8 has no prohibitory effect. Shepler v. Crucible Fuel Oil Co. of America, 60 F. Supp. 260 ( $\mathrm{Pa}$. , r943); White v. Witwer Grocer Co., I32 F. 2d I08 (C.C.A. 8th, r942); Remer v. Czaja, 36 F. Supp. 629 (Md., 1941). That this was the intent of Congress is indicated by the fact that violation of Section 18 was not included among the prohibitions of Section ${ }_{5}(\mathrm{a})$, and that penalties were not provided for its enforcement under Section I6 of the Act. 52 Stat. I068 (I938), 29 U.S.C.A. $\$ \$ 215$, 216 (r942). See also the interpretation of the Wage and Hour Administrator in Wage and Hour Division, Interpretative Bulletin No. 4, at p. 7 (1940).

$$
{ }^{28} 325 \text { U.S. 419 (1945). } \quad{ }^{39} 325 \text { U.S. } 427 \text { (I945). }
$$

${ }^{30}$ This is shown by the following example. A worker is assigned a basic hourly rate of $\$ .90$. His average hourly earning from piecework is $\$ I_{\text {., }}$ which is lower than his overtime rate of $\$$ I.35. However, if he works 50 hours a week, the regular workweek being 40 hours, his piecework earnings of $\$ 50$. willstill be somewhat higher than his total pay at regular and overtime rates $(\$ .90 \times 40+\$$ I. $35 \times$ Io $=\$ 49.50)$. The worker's effective hourly rate thus does not increase until he works considerably more than the statutory maximum hours. This was also the effect of the Belo plan.

${ }^{32} 325$ U.S. 4I9, 424 (r945). 
given in the Missel case. In a dissenting opinion Mr. Chief Justice Stone indicated that the majority opinion was inconsistent with the Belo case. He suggested that there was nothing in the Act which prevented in the Youngerman case the apportioning of the amount by which the bonus or piecework pay exceeded the guaranteed hourly wages, in proportion to the regular and overtime hours worked; ${ }^{32}$ yet not even in his opinion was it argued that the contract hourly rate validated this plan, as was held in the Belo case. ${ }^{33}$

Since these two latest decisions of the Supreme Court it has already become clear that the Court has failed again to settle definitely the interpretation of Section $\eta$ (a). The existing uncertainty is due to the Supreme Court's insistence on harmonizing its latest holdings with that in the Belo case. In their most recent decisions the federal courts have reflected the holding of the Youngerman and Harnischfeger cases; ${ }^{34}$ but in a case closely approximating the fact-situation in the Belo case, a lower court is practically forced to hold that the contract rate is the regular rate. ${ }^{35}$

Thus, in spite of the impressive array of cases in point, the employer who has readjusted his wage-and-hourpolicy for the purpose of the Act is still faced with some uncertainty as to the legality of this plan in so far as he relies on the Belo case. It is clear now that an hourly rate must be fixed and agreed upon by employers and employees since it will not be implied if a straight periodical wage is paid. Production or incentive bonuses and piecework earnings are likewise

${ }^{32} 325$ U.S. 427,434 (I945). The Chief Justice's suggestion is aimed to overcome the majority's objection that however high a piecework wage is it cannot of itself be taken to include any of the wage differential which the Act requires for overtime hours. He proposes this solution: If, for example, the piecework earnings for a 50 hour workweek total $\$ 66$ and the minimum at the set hourly rate of $\$ \mathrm{I}$ totals $\$ 55(\$ \mathrm{I} \times 40+\$ 1.50 \times 10)$, the $\$ \mathrm{II}$ by which the piecework pay exceeds the minimum hourly wage should be apportioned and added to the hourly rate when computing the worker's wage. Thus, on the worker's paycheck the regular rate in this instance should be raised to $\$ 1.20$. This rate, when multiplied by the hours worked, will produce the desired amount of $\$ 66(\$ \mathrm{r} .20 \times 40+\$ 1.80 \times 10=\$ 66)$.

Such a computation may be in harmony with the Belo case, but overlooks completely the decision in United States v. Rosenwasser, 323 U.S. 360 (I944), in which the Chief Justice concurred, which held that piecework wages had to be reduced to an hourly rate under the Fair Labor Standards Act. If such arithmetical juggling as suggested here by Mr. Chief Justice Stone is permissible, a straight piecework wage as paid in the Rosenwasser case, or even a straight weekly wage as in the Missel case, can easily be apportioned in the same way by a mere bookkeeping transaction. See also Walling v. Castle, I53 F. $2 \mathrm{~d} 923$ (C.C.A. 5th, I946), where a similar arrangement was disallowed.

${ }^{33}$ In a short and somewhat obscure concurring opinion, M.r. Justice Frankfurter suggests that the "regular rate" in the Belo plan was not "a mere artifice unrelated to wage-earning actualities." 325 U.S. 427, 433 (I945). He fails to make clear why this is so, however.

${ }^{34}$ Watkins v. Hudson Coal Co., I5I F. 2d 3 II (C.C.A. 3d, I945); Walling v. Uhlman Grain Co., ${ }_{5}$ I F. $2 \mathrm{~d} 38 \mathrm{I}$ (C.C.A. 7 th, 1945 ). In the latter case the circuit court of appeals which had originally approved the Harnischfeger plan on the strength of the Belo case only to have its holding reversed by the Supreme Court, stated: "If the Supreme Court has not repudiated its holding in the Belo case, it has come so close as to leave no room for its application except upon an identical state of facts." Ibid., at 383 .

${ }_{35}$ Walling v. Halliburton Oil Well Cementing Co., I52 F. 2d 622 (C.C.A. gth, 1945). The dissenting opinion in this case contended that the Belo case was no longer reliable as a precedent. Tbid., at 624 . 
subject to overtime payment. The "regular rate" cannot fluctuate with the number of hours worked. The split-day plan is illegal because the hourly rates are fictitious. As for the current judicial construction of "regular rate," the only safe statement is that, where straight-time pay, bonus, or piecework earnings are commuted into hourly wages, it is the quotient of wages divided by hours, except in a situation like the Belo case, where it is the contract rate. The courts, however, because of the extensive inroads which have been made on the holding in that case, will be inclined to seize upon the slightest fact in order to distinguish a similar case, and to apply the general rule.$^{6}$ Probably the only safe plan for an employer who seeks to avoid an increase in total pay due to overtime is an actual reduction of the hourly rate effected through collective bargaining, but even such a reduction has been closely scrutinized and voided because it was found to be only a bookkeeping transaction. ${ }^{37}$

Perhaps the only justification for the Belo case is that its plan sought to stabilize the wages of employees with variable working hours. However, other plans with a similar aim have been voided because they did not comply with the requirements of the Act. ${ }^{38}$ The Wage and Hour Administrator has proposed two stabilization plans which he considers legal; the time-off plan and the prepayment plan. ${ }^{39}$ Under the first of these plans an employee who works overtime in one week is laid off a sufficient number of hours during some other week to offset the amount of overtime worked and is paid a stable wage biweekly or monthly. In the prepayment plan the employer pays the worker a sum in excess of what he earns in a particular week and the excess is considered a prepayment for overtime work in a subsequent week. Neither of the two plans is very satisfactory because both involve considerable bookkeeping and are, according to the Administrator, inapplicable to salaried employees working irregular hours $;^{4^{\circ}}$ thus it is not surprising that the search for another legal plan continues.

${ }^{36}$ Note 34 supra.

37 Watkins v. Hudson Coal Co., I5I F. 2d 3 II (C.C.A. 3d, I945), where the court, after a close examination of old and new sample paychecks, found that the new weekly pay was exactly the same as the old wage although if the new "regular rate" had been properly used in the computation the new total would have varied very slightly from the old pay. The court concluded that the adopted "regular rate" had not actually been used in the computation and held the plan void. In indicating the difficulties involved in an actual reduction in the "regular rate," the Administratorhas pointed out that employees are unlikely to acquiesce in a reduction unless the employer assures them that they will not lose any pay by it. Yet, if the employer guarantees them their former wages, their true rate of pay remains unchanged, while if there is no express or implied guaranty, the employer's payment of wages for less than a full week on the basis of the old rate would indicate that the adopted rate is a mere bookkeeping figure for the computation of overtime and not the true rate. Wage and Hour Division, Interpretative Bulletin No. 4, at p. 7 (1940).

${ }^{8}$ Walling v. Castle, I53 F. $2 d 923$ (C.C.A. 5th, I946); Walling v. Helmerich \& Payne, $3^{23}$ U.S. 37 (rg44).

39 Wage and Hour Division, Interpretative Bulletin No. 4 (I940).

$4^{\circ} \mathrm{Ibid}$., at II and $\mathrm{I} 6$. This results from the consideration that, since a salaried employee is entitled to full pay even if he has worked less than the regular time in a week, full pay for such a week cannot be said to be compensation for excess hours in another week. 